\title{
Learning to live with hearing voices
}

\section{Emily Knoll discusses the therapeutic interventions that have helped her come to terms with hearing voices}

\section{Emily Knoll}

It was after undergoing spinal surgery, and when I felt that I was going down a black hole with my doctorate, that I began to hear distressing voices that seemed to come from outside my head. I was embarrassed by the things that the voices were saying to me, so I didn't tell anyone. I also thought that if I told a doctor, I would be sent to a psychiatric hospital. So, instead of seeking help, I dropped out of university.

Two years later I experienced what I now understand to have been a psychotic breakdown. Sometimes it felt as if two men and a spiteful woman were actually there, in my room. I held my breath and listened.

"Emily is waiting for us to disappear," said the woman cruelly. "We're not going away," the man with the brittle voice replied. I started to play with their words in my head, wondering what they meant by what they had said. Would they really go? I had no idea.

\section{Medication was not the answer}

It was still several months before I admitted myself to a psychiatric hospital, and there I received a diagnosis of "schizo-affective disorder." The diagnosis shattered my fragile confidence, as I began to see myself as a collection of symptoms. I had three admissions on a busy psychiatric ward. Despite taking antipsychotic medication to suppress the voices, I was still hearing them. I didn't tell anyone as I felt shame. But hearing the voices made me very withdrawn and distracted. This behaviour could be a clue for clinicians that voice-hearing is continuing.

\section{Changing my relationship with the voices}

Some time later a GP asked me if I was still hearing voices, which I was. She then referred me to an understanding psychiatrist, who asked me what the voices said. I just told her they said cruel things to me and I explained that medication had previously failed to stop them. She told me it was possible to live with some level of hearing voices. This was the first time I'd been told this, and I found it helpful.

I went on to have therapy with a psychodynamic therapist who explained that even though the voices sounded separate, it was important to recognise that they were part of me-the critical part of myself. This also helped me to realise I could have some measure of control.

\section{Learning strategies to cope}

I went on to have therapy for seven years. I only wanted to take a low amount of medication and only during times of stress, partly because they did not eliminate my voices and also because I disliked the side effects, such as weight gain.

So I was keen to learn strategies for coping with the distressing voices. My therapist encouraged me to talk back to them. Sometimes I questioned them, other times I told them to "shut up." I also learnt to set boundaries and would ignore the voices when I was studying. I found that when I stopped being frightened of the voices, they became less critical. Sometimes the voices stopped completely for several hours or days. Stress was often a trigger for hearing voices, so I learnt ways to reduce it, such as practising mindfulness.

I now finally have a doctorate from university, which investigates emotional aspects of the experience of hearing voices in the English adult population. I recently used my experience of psychosis to write a memoir called Emily's Voices.

\section{What you need to know \\ - People might be too ashamed to admit to hearing voices, so it could be helpful to ask about them directly \\ - Antipsychotic medication is not always successful in eliminating voices, so it might help people to suggest they could live with their own voices too \\ - Consider telling people that voice hearers can have good recoveries, careers, and families-this helps to challenge stigma and shame}

Education into practice

- Have you heard a patient describe hearing voices before? Does this article offer you new insights on how it might feel?

- What questions or observations do you use to identify patients who might be hearing voices? Does this article offer you ideas on how to better approach the topic?

- How might you reduce concern or stigma around talking about voices?

- Have you experience in talking with patients about how to manage voices? Does this article offer you ideas? 


\section{Further information}

- Hearing the Voice (www.hearingthevoice.org)—a large interdisciplinary study of voice-hearing based at Durham University

- Emily has written a memoir of her experience of voice-hearing and her experience of mental health services: www.amazon.com/EMILYSVOICES-Emily-Knoll/dp/1999863801
Competing interests: I have read and understood BMJ policy on declaration of interests and declare the following: None.

Emily Knoll is a pseudonym.

Published by the BMJ Publishing Group Limited. For permission to use (where not already granted under a licence) please go to http://group.bmj.com/group/rights-licensing/ permissions 